\title{
Persepsi Mahasiswa Terhadap Pembelajaran Daring pada Mata Kuliah Metodologi Penelitian Kualitatif
}

\author{
Fatkhul Imron \\ Pendidikan Kepelatihan Olahraga, Universitas Tunas Pembangunan, imronfatkhul@gmail.com \\ Teguh Santosa \\ Pendidikan Kepelatihan Olahraga, Universitas Tunas Pembangunan, teguhgelora@gmail.com \\ Winda Ayu Cahya Fitriani \\ Manajemen Pajak, Universitas PGRI Madiun, winda.ayu.cahya@gmail.com
}

\begin{abstract}
Abstrak
Tujuan penelitian ini adalah untuk mengetahui persepsi mahasiswa ditinjau dari aspek pengalaman belajar mahasiswa, kapabilitas dosen, dan sarana prasarana terhadap pembelajaran daring pada mata kuliah Metodologi Penelitian Kualitatif di Program Studi PKO UTP”. Penelitian ini merupakan jenis penelitian survey dengan pendekatan kuantitatif. Hasil penelitian ditinjau dari aspek kapabilitas dosen, menunjukkan persepsi positif mahasiswa selama perkuliahan daring. Hal ini dikarenakan dosen menggunakan beberapa aplikasi pembelajaran seperti Edmodo, Zoom, Google Meet, dan Youtube dalam perkuliahan sehingga mahasiswa tidak mengalami kebosanan dalam belajar, materi dapat disampaikan secara detail dan mendalam sehingga terjadi diskusi interaktif di dalam kelas. Pada aspek pengalaman belajar, mahasiswa memberikan persepsi negatif karena kurangnya pemahaman materi dan tidak adanya buku ajar yang dimiliki. Selain itu, mahasiswa mengalami stress dengan banyaknya tugas yang diberikan oleh dosen. Pada aspek sarana prasarana, mahasiswa mengalami kesulitan dalam mengikuti pembelajaran daring dikarenakan kurangnya kuota, lemahnya sinyal, dan terbatasnya perangkat elektronik yang sesuai dengan standar belajar daring.
\end{abstract}

Kata Kunci: Pembelajaran, Daring, Persepsi

\section{PENDAHULUAN}

Pendidikan merupakan salah satu kebutuhan primer yang dapat membentuk manusia seutuhnya untuk memperoleh kualitas nilai dalam kehidupan. Pendidikan memiliki tujuan mencerdaskan kehidupan bangsa, sehingga melalui pendidikan diharapkan dapat memperbaiki pola pikir seseorang untuk mencapai puncak kesuksesan. Pendidikan sebagai peningkatan sumber daya manusia menjadi sangat penting di semua lini kehidupan terutama di masa pandemi seperti sekarang ini. Sejak bulan Maret 2020 sampai sekarang pendidikan seakan mengalami stagnasi yang berlangsung terus-menerus. Semua pembelajaran tatap muka di kelas diberhentikan dan digantikan dengan pembelajaran daring (dalam jaringan) karena pembelajaran daring dianggap menjadi alternatif dalam menyelesaikan permasalahan tersebut. Banyak guru dan dosen yang melakukan pembelajaran daring melalui media teknologi, seperti melalui Whatsapp, Email, Google, Google meet, Zoom, media sosial, bahkan menggunakan aplikasi yang lain. Semua peserta didik dipastikan untuk belajar dari rumah dan mulailah dengan pembelajaran yang kesemuanya melakukan kegiatan berbasis internet.

Dosen dan mahasiswa dituntut untuk memanfaatkan aplikasi teknologi informasi yang tersedia agar pembelajaran jarak jauh tetap berjalan. Interaksi pembelajaran online dilakukan dengan mengirimkan tugas via aplikasi e-learning, memberikan tugas, diskusi online, dan meninjau proses pembelajaran (Allo, 2020). Perkembangan teknologi memberikan dampak positif bagi pelaksanaan pembelajaran (Keengwe, J., \& Georgina, D. 2012). Konsep dari pembelajaran jarak jauh yang lebih dikenal dengan istilah distance 
learning atau distance education, yaitu suatu sistem pendidikan dimana terdapat pemisahan antara pengajar dan siswa baik secara ruang dan/atau waktu. "Distance learning" dikembangkan pertama kali di Amerika Serikat, Perancis, Jerman, dan Inggris pada pertengahan tahun 1800. Pada tahun 1840, Sir Isac Pitman mengajar jarak jauh menggunakan surat. Dan pada tahun 1980 an, International Correspondence Schools (ICS) membengun metode perkuliahan "home-study courses" yang pada saat itu dikarenakan faktor kemananan

Dalam rangka meningkatkan kualitas pendidikan daring tersebut dosen dituntut untuk meningkatkan inovasi pembelajaran, salah satunya dengan pembelajaran berbasis audiovideo learning, namun hal tersebut ternyata belum bisa sepenuhnya dilaksanakan. Dosen sebagai penyelenggara pendidikan yang seharusnya mengoptimalkan kegiatan belajar mengajar, akan tetapi dalam fungsinya, banyak dosen yang masih memiliki banyak kendala seperti gagap teknologi (gaptek), terkendala sinyal dan kuota, dan kurangnya kreativitas dalam membuat materi pembelajaran. Maka dari itu banyak dosen yang hanya menggunakan aplikasi seperti Whatsapp berbentuk penugasan untuk menggugurkan materi perkuliahan. Namun ada juga beberapa dosen yang mengajar menggunakan media seperti Zoom, Google Meet, dan aplikasi pembelajaran e-Learning karena menganggap aplikasi tersebut lebih efektif jika dibandingkan dengan aplikasi Whatsapp sehingga pembelajaran dinilai lebih efektif digunakan pada perkuliahan.

Salah satu mata kuliah wajib pada program studi Pendidikan Kepelatihan Olahraga Universitas Tunas Pembangunan Surakarta yaitu "Metodologi Penelitian Kualitatif". Mata kuliah tersebut di masa pandemi ini harus dilaksanakan secara daring. Hal ini menuntut mahasiswa untuk dapat berpikir secara komprehensif agar bisa memahami konsep perkuliahan tersebut dengan baik. Sayangnya dengan pembelajaran yang berbasis daring tersebut membuat mahasiswa seakan mengalami sedikit kesulitan dalam memahami secara utuh. Banyak mahasiswa yang merasa kebingungan ataupun tidak mengerti dengan materi yang telah disampaikan oleh dosennya. Bahkan banyak mahasiswa yang merasa kebosanan mengikuti perkuliahan dikarenakan materi ajar yang kurang bervariasi.

Berdasarkan latar belakang tersebut, maka peneliti merumuskan "Bagaimana persepsi mahasiswa ditinjau dari aspek pengalaman belajar mahasiswa, kapabilitas dosen, dan sarana prasarana terhadap pembelajaran daring pada mata kuliah Metodologi Penelitian Kualitatif di Program Studi PKO UTP”.

Mahasiswa PKO UTP harus memiliki persepsi yang sama untuk memproses informasi yang disampaikan oleh dosen ketika mengikuti perkuliahan daring. Sebagaimana menurut Matsumoto \& Juang yang dikutip oleh Sarwono (2014), menyatakan bahwa persepsi adalah proses mengumpulkan informasi mengenai dunia melalui pengindraan yang kita miliki. Disisi lain Siagian (1995) menerangkan bahwa terdapat 3 faktor yang mempengaruhi persepsi seseorang, yaitu: (a) Faktor pelaku persepsi, yaitu diri orang yang bersangkutan apabila seseorang melihat sesuatu dan berusaha memberikan interpretasi tentang ayang dilihatnya itu, (b) Faktor sasaran persepsi, dapat berupa orang, benda atau peristiwa, dan (c) Faktor situasi, faktor situasi merupakan keadaan seseorang ketika melihat sesuatu dan mempersepsinya. Hal ini membuat persepsi merupakan hal yang sangat penting dalam sebuah pembelajaran.

Pembelajaran merupakan sebuah korelasi yang dihasilkan oleh peserta didik dan lingkungannya, sehingga mengakibatkan transformasi kearah yang lebih baik. Dalam setiap aktivitas belajar, situasi eksternal harus diubah untuk menghidupkan, menunjang, dan mempertahankan proses belajar secara internal 
untuk menghasilkan sebuah kegiatan belajar yang baik (Gagne, 1985). Selain itu, pengertian pembelajaran juga dikemukakan oleh Miarso yang menyatakan bahwa pembelajaran adalah usaha pendidikan yang dilaksanakan secara sengaja, dengan tujuan yang telah ditetapkan terlebih dahulu sebelum proses dilaksanakan, serta pelaksanaanya terkendali (dikutip oleh Siregar dan Hartini Nara, 2011). Berdasarkan pendapat beberapa para ahli tersebut dapat ditarik kesimpulan bahwa pembelajaran merupakan proses yang melibatkan semua komponen pembelajaran, baik itu secara internal maupun eksternal dengan bertujuan pencapaian kompetensi peserta didik dan situasi belajar mengajar yang baik sesuai dengan tujuan yang telah ditetapkan.

Pembelajaran sangat berpengaruh terhadap bagaimana peserta didik berpikir, berkreasi, dan bersikap. Pembelajaran merupakan salah satu hal yang bisa menentukan kualitas kehidupan peserta didik. Ketika peserta didik mengikuti kegiatan pembelajaran, diharapkan persepsi yang dihasilkan sesuai dan seirama dengan apa yang dikemukakan oleh pendidik (guru/dosen) meskipun pembelajaran dilaksanakan secara daring seperti situasi pada masa pandemi ini.

Pembelajaran daring merupakan sebuah transformasi pembelajaran futuristik yang menggunakan teknologi sebagai salah satu sarananya. Pengajar (guru/dosen) menyampaikan materi dengan memanfaatkan beberapa aplikasi agar tercipta interaksi yang memudahkan peserta didik dalam mendapatkan materi belajar tanpa harus melakukan tatap muka. Pada dasarnya, pembelajaran daring merupakan salah satu solusi di masa pandemi agar para pendidik dan peserta didik dapat mengutamakan kesehatan tapi tidak melupakan kewajiban belajar yang seharusnya.

Sehubungan dengan hakikat pembelajaran daring, Horton (2010) mengklarifikasikan aktivitas peserta didik dalam menggunakan pembelajaran daring ke dalam tiga jenis yaitu Absord, do, connect. Dari ketiga aktivitas tersebut, dapat disimpulakn bahwa (1) Absorb, adalah proses yang merangsang pemikiran dan pengetahuan peserta didik melalui kegiatan kognitif, seperti membaca, melihat, dan mendengar, (2) Do, adalah sebuah proses mendapatkan pengalaman dari apa yang telah dipelajari, seperti latihan dan simulasi, dan (3) Connect, adalah proses menghubungkan pengetahuan dan pengalaman menjadi sebuah sudut pandang yang baru, seperti praktek lapangan dan bercerita.

\section{METODE}

Penelitian ini merupakan jenis penelitian survey dengan pendekatan kuantitatif. Kerlinger (2006), mengemukakan bahwa jenis survei dapat dikelompok-kelompokkan secara mudah berdasarkan metode-metode yang digunakan untuk memperoleh informasi sebagai berikut : wawancara pribadi, kuesioner, lewat pos, panel, dan telepon. Adapun penelitian ini untuk menganalisis persepsi mahasiswa terhadap pembelajaran daring pada mata kuliah Metodologi Penelitian Kualitatif di program studi Pendidikan Kepelatihan Olahraga. Penelitian ini dilaksanakan di kelas online pada mata kuliah Metodologi Penelitian Kualitatif PKO FKIP UTP yang dilaksanakan pada bulan April sampai Juli 2021.

Data yang dikaji atau dikumpulkan dalam penelitian ini berupa data kuantitatif yang berbentuk presentase dan diperoleh peneliti dengan menggunakan instrumen kuesioner yang diisi secara daring oleh mahasiswa dengan menggunakan Google Form. Adapun data yang dikumpulkan memfokuskan diri pada:

a. Pengalaman belajar mahasiswa dalam perkuliahan daring.

b. Kapabilitas (kemampuan dosen) dalam perkuliahan daring.

c. Sarana dan prasarana yang digunakan dalam perkuliahan daring. 
Sumber data primer penelitian ini adalah mahasiswa semester 6 yang menempuh mata kuliah Metodologi Penelitian Kualitatif. Sumber data sekunder dalam penelitian ini dokumen yang berbentuk kuesioner dan wawancara terstruktur. Pengumpulan data menggunakan instrumen yang dikembangkan dengan skala likert. Analisis data menggunakan statistik deskriptif yang berupa persentase.

\section{HASIL DAN PEMBAHASAN Hasil}

Penelitian ini merupakan penelitian yang mengukur bagaimana persepsi mahasiswa terhadap pembelajaran daring terutama dalam mata kuliah "Metodologi Penelitian Kualitatif". Adapun data yang ditampilkan dalam penelitian ini diperoleh dari mahasiswa Pendidikan Kepelatihan Olahraga semester 6 yang menempuh mata kuliah tersebut. Responden yang berpartisipasi dalam penelitian ini menunjukkan bahwa mayoritas mereka berjenis kelamin laki-laki yang berjumlah 17 orang (74\%) orang dan perempuan berjumlah 6 orang $(26 \%)$.

Adapun data penelitian disajikan dalam beberapa bagian dan diperoleh melalui angket (kuesioner) dan wawancara terstruktur. Data angket dari responden (mahasiswa) diperoleh dengan mengisi google formulir yang sudah disiapkan oleh peneliti. Data yang sudah didapatkan secara lengkap akhirnya dijabarkan dalam tabel dan deskripsi sebagai berikut:

Tabel 1. Persepsi Mahasiswa Terhadap Pembelajaran Daring

\begin{tabular}{|c|l|c|}
\hline No & \multicolumn{1}{|c|}{ Pernyataan } & $\begin{array}{c}\text { Persentase } \\
\text { Mayoritas } \\
\text { Responden }\end{array}$ \\
\hline \multicolumn{2}{|c|}{ Aspek Pengalaman Belajar Mahasiswa } \\
\hline 1 & $\begin{array}{l}\text { Pembelajaran daring sangat } \\
\text { membantu dalam }\end{array}$ & $\begin{array}{c}47,8 \% \\
\text { (Setuju) }\end{array}$ \\
& $\begin{array}{c}\text { menggantikan pembelajaran di } \\
\text { kelas selama Pandemi Covid } \\
\end{array}$ & \\
\hline 2 & $\begin{array}{l}\text { Pembelajaran daring yang } \\
\text { diberikan oleh dosen dapat }\end{array}$ & $\begin{array}{c}65,2 \% \\
\text { (Setuju) }\end{array}$ \\
\hline
\end{tabular}

\begin{tabular}{|c|c|c|}
\hline & diterima dengan jelas & \\
\hline 3 & $\begin{array}{l}\text { Pembelajaran daring yang } \\
\text { diberikan oleh dosen dapat } \\
\text { diterima sebagian kecil saja }\end{array}$ & $\begin{array}{l}60,9 \% \\
\text { (Setuju) }\end{array}$ \\
\hline 4 & $\begin{array}{l}\text { Pembelajaran daring mudah } \\
\text { untuk dipahami }\end{array}$ & $\begin{array}{l}43,5 \% \\
\text { (Setuju) } \\
\end{array}$ \\
\hline 5 & $\begin{array}{l}\text { Pembelajaran daring sulit } \\
\text { untuk dipahami }\end{array}$ & $\begin{array}{l}52,2 \% \\
\text { (Setuju) }\end{array}$ \\
\hline 6 & $\begin{array}{l}\text { Saya sangat senang mengikuti } \\
\text { perkuliahan Metodologi } \\
\text { Penelitian Kualitatif secara } \\
\text { daring }\end{array}$ & $\begin{array}{l}60,9 \% \\
\text { (Setuju) }\end{array}$ \\
\hline 7 & $\begin{array}{l}\text { Metode pembelajaran daring } \\
\text { memudahkan saya dalam } \\
\text { menerima materi Metodologi } \\
\text { Penelitian Kualitatif }\end{array}$ & $\begin{array}{l}52,2 \% \\
\text { (Tidak } \\
\text { Setuju) }\end{array}$ \\
\hline 8 & $\begin{array}{l}\text { Metode pembelajaran daring } \\
\text { menyulitkan saya dalam } \\
\text { menerima materi Metodologi } \\
\text { Penelitian Kualitatif }\end{array}$ & $\begin{array}{l}56,5 \% \\
\text { (Setuju) }\end{array}$ \\
\hline 9 & $\begin{array}{l}\text { Saya sangat memahami } \\
\text { penjelasan dari teman ketika } \\
\text { presentasi secara daring }\end{array}$ & $\begin{array}{l}52,2 \% \\
\text { (Setuju) }\end{array}$ \\
\hline 10 & $\begin{array}{l}\text { Sosial distancing membuat } \\
\text { stress karena adanya tugas } \\
\text { yang banyak dari dosen }\end{array}$ & $\begin{array}{l}52,2 \% \\
\text { (Setuju) }\end{array}$ \\
\hline 11 & $\begin{array}{l}\text { Pembelajaran daring sangat } \\
\text { menarik }\end{array}$ & $\begin{array}{l}56,5 \% \\
\text { (Setuju) } \\
\end{array}$ \\
\hline 12 & $\begin{array}{l}\text { Pembelajaran daring sangat } \\
\text { sulit }\end{array}$ & $\begin{array}{l}56,5 \% \\
\text { (Setuju) } \\
\end{array}$ \\
\hline 13 & $\begin{array}{l}\text { Pembelajaran secara daring } \\
\text { membuat lebih semangat } \\
\text { ketika belajar }\end{array}$ & $\begin{array}{l}56,5 \% \\
\text { (Setuju) }\end{array}$ \\
\hline 14 & $\begin{array}{l}\text { Saya merasa rugi jika proses } \\
\text { perkuliahan tatap muka di } \\
\text { kelas diganti dengan } \\
\text { pembelajaran daring }\end{array}$ & $\begin{array}{l}43,5 \% \\
\text { (Setuju) }\end{array}$ \\
\hline 15 & $\begin{array}{l}\text { Saya tetap ingin melanjutkan } \\
\text { proses pembelajaran secara } \\
\text { daring jika Pandemi Covid } 19 \\
\text { ini telah berakhir }\end{array}$ & $\begin{array}{l}47,8 \% \\
\text { (Sangat } \\
\text { Tidak } \\
\text { Setuju) } \\
\end{array}$ \\
\hline \multicolumn{3}{|c|}{ Aspek Kapabilitas Dosen } \\
\hline 1 & $\begin{array}{l}\text { Dosen memberikan } \\
\text { perkuliahan daring selama } \\
\text { pandemi Covid } 19\end{array}$ & $\begin{array}{l}65,2 \% \\
\text { (Setuju) }\end{array}$ \\
\hline 2 & $\begin{array}{l}\text { Dosen menggunakan beberapa } \\
\text { aplikasi untuk perkuliahan } \\
\text { daring }\end{array}$ & $\begin{array}{l}69,6 \% \\
\text { (Setuju) }\end{array}$ \\
\hline 3 & $\begin{array}{l}\text { Dosen memberikan arahan dan } \\
\text { tujuan pembelajaran sebelum } \\
\text { memulai pembelajaran daring }\end{array}$ & $\begin{array}{l}78,3 \% \\
\text { (Setuju) }\end{array}$ \\
\hline 4 & $\begin{array}{l}\text { Dosen selalu memberikan } \\
\text { bimbingan terhadap materi } \\
\text { pembelajaran yang belum }\end{array}$ & $\begin{array}{l}78,3 \% \\
\text { (Setuju) }\end{array}$ \\
\hline
\end{tabular}




\begin{tabular}{|c|c|c|}
\hline & dipahami secara daring & \\
\hline 5 & $\begin{array}{l}\text { Cara dosen memberikan } \\
\text { penjelasan dalam pembelajaran } \\
\text { daring membuat pembelajaran } \\
\text { lebih menarik dan mudah } \\
\text { dipahami }\end{array}$ & $\begin{array}{c}65,2 \% \\
\text { (Setuju) }\end{array}$ \\
\hline 6 & $\begin{array}{l}\text { Cara dosen memberikan } \\
\text { penjelasan secara daring } \\
\text { membuat saya tidak bosan }\end{array}$ & $\begin{array}{c}65,2 \% \\
\text { (Setuju) }\end{array}$ \\
\hline \multicolumn{3}{|c|}{ Aspek Sarana dan Prasarana } \\
\hline 1 & $\begin{array}{l}\text { Materi Metodologi Penelitian } \\
\text { Kualitatif yang diajarkan } \\
\text { secara daring tersedia dengan } \\
\text { baik di salah satu aplikasi } \\
\text { belajar }\end{array}$ & $\begin{array}{c}60,9 \% \\
\text { (Setuju) }\end{array}$ \\
\hline 2 & $\begin{array}{l}\text { Pembelajaran secara daring } \\
\text { dapat mempermudah dalam } \\
\text { mendiskusikan pelajaran } \\
\text { kepada dosen }\end{array}$ & $\begin{array}{l}47,8 \% \\
\text { (Tidak } \\
\text { Setuju) }\end{array}$ \\
\hline 3 & $\begin{array}{l}\text { Pelaksanaan perkuliahan } \\
\text { secara daring dapat saya akses } \\
\text { dengan mudah dimanapun saya } \\
\text { berada }\end{array}$ & $\begin{array}{c}47,8 \% \\
\text { (Setuju) } \\
47,8 \% \\
\text { (Tidak } \\
\text { Setuju) } \\
\end{array}$ \\
\hline 4 & $\begin{array}{l}\text { Perkuliahan secara daring } \\
\text { memudahkan saya dalam } \\
\text { mengirim tugas tepat waktu }\end{array}$ & $\begin{array}{c}43,5 \% \\
\text { (Setuju) }\end{array}$ \\
\hline 5 & $\begin{array}{l}\text { Saya merasa tidak ada } \\
\text { kerumitan belajar dengan } \\
\text { penerapan metode daring }\end{array}$ & $\begin{array}{l}43,5 \% \\
\text { (Tidak } \\
\text { Setuju) }\end{array}$ \\
\hline 6 & $\begin{array}{l}\text { Banyak hambatan yang } \\
\text { ditemui ketika pelaksanaan } \\
\text { pembelajaran daring (seperti } \\
\text { kuota, sinyal, dll) }\end{array}$ & $\begin{array}{l}69,6 \% \\
\text { (Sangat } \\
\text { Setuju) }\end{array}$ \\
\hline
\end{tabular}

Pada tabel 1, data mengenai "Persepsi mahasiswa dalam pembelajaran daring terhadap mata kuliah Metodologi Penelitian Kualitatif" selama pandemi Covid-19 dideskripsikan menjadi 3 aspek, yaitu: aspek pengalaman belajar mahasiswa, kapabilitas dosen, serta sarana dan prasarana.

Berdasarkan data yang disajikan, dapat dilihat bahwa dari aspek pengalaman belajar mahasiswa, pembelajaran daring sangat membantu dalam menggantikan pembelajaran tatap muka di kelas. Hal ini dinyatakan melalui angket yang telah diisi responden, bahwa $47,8 \%$ responden menyatakan setuju. Selanjutnya menurut responden, pembelajaran daring yang diberikan oleh dosen dapat diterima dengan jelas $(65,2 \%)$, namun disisi lain responden juga menyatakan bahwa pembelajaran daring yang diberikan oleh dosen hanya dapat diterima sebagian kecil saja $(60,9 \%)$, artinya terdapat kebingungan yang dialami oleh responden dan bisa dianalogikan bahwa pembelajaran daring yang diterima oleh mahasiswa hanya dapat diterima sebagian saja. Hal ini bisa dibuktikan dengan pernyataan selanjutnya yang menyatakan bahwa 52,2\% mahasiswa setuju jika mereka kesulitan memahami pembelajaran yang dilaksanakan secara daring.

Kemudian sebesar $60,9 \%$ responden sangat senang ketika mengikuti perkuliahan Metodologi Penelitian Kualitatif secara daring. Namun disisi lain, 56,5\% responden mengalami kesulitan dalam menerima materi yang diberikan oleh dosen dan 52,2\% responden menyatakan tidak setuju bahwa materi Metodologi Perkuliahan Kualitatif itu tergolong mudah. Maka dari itu, materi dalam perkuliahan tersebut memang sangat sulit diterima oleh mahasiswa karena mereka harus memahami secara komprehensif, mendalam, dan berkesinambungan. Perlu adanya bimbingan yang secara kontinyu yang dilaksanakan oleh dosen dan praktek secara langsung untuk memahami materi Metodologi Penelitian Kualitatif tersebut.

Pada tabel 1 juga menampilkan data $52,2 \%$ responden memahami penjelasan dari teman ketika mempresentasikan tugas secara daring dan 56,5\% mereka setuju bahwa pembelajaran daring membuat lebih semangat belajar. Namun disisi lain, adanya social distancing ini banyak membuat stress karena tugas yang banyak dan menumpuk dari dosen, sehingga mahasiswa mengalami kebosanan. Sebesar 52,2\% responden setuju dengan pernyataan tersebut. Dengan demikian dapat disimpulkan bahwa $56,5 \%$ responden menyatakan pembelajaran daring ini sangatlah sulit, padahal juga sangat menarik. 
Selanjutnya terdapat data yang menyatakan bahwa responden merasa dirugikan dengan adanya perkuliahan daring untuk mengganti tatap muka, presentase $43,5 \%$ setuju dengan pernyataan tersebut. Menurut mereka, tatap muka dinilai lebih efektif dibandingan dengan pembelajaran daring. Dan $47,8 \%$ responden sangat tidak setuju jika proses pembelajaran daring ini tetap dilaksanakan bila pandemi telah berakhir. Namun presentase tersebut masih dibawah 50\%. Artinya tidak semua berpendapat sama. Ada responden yang merasa tidak dirugikan dengan adanya daring dan ada yang masih antusias untuk melanjutkan pembelajaran daring meskipun pandemic sudah berakhir.

Terkait aspek kapabilitas dosen, pada tabel 1 menunjukkan data bahwa 65,2\% dosen telah memberikan perkuliahan selama pandemi ini. Sebelum memulai pembelajaran, dosen telah memberikan arahan dan tujuan pembelajaran, 78,3\% menjawab setuju. Ketika memberikan penjelasan tentang materi pembelajaran, dosen juga telah membuat pembelajaran lebih menarik dan mudah dipahami. Dan 65,2\% responden setuju bahwa penjelasan yang telah diberikan oleh dosen membuat mereka tidak bosan mengikuti pembelajaran. Selain itu menurut $69,6 \%$ responden setuju bahwa dosen juga telah menggunakan beberapa aplikasi seperti Edmodo, Youtube, Google meet, dan Zoom untuk menunjang pembelajaran. Kemudian dosen juga telah memberikan bimbingan terhadap materi yang belum dipahami oleh mahasiswa, 78,3\% responden setuju dengan hal tersebut. Maka dari itu dapat disimpulkan bahwa dosen telah memiliki kapabilitas yang baik dalam mengajarkan materi Metodologi Penelitian Kualitatif secara efektif dan inovatif.

Dalam hal penggunaan sarana dan prasarana, data pada tabel 1 menunjukkan bahwa menurut $60,9 \%$ responden, materi Metodologi Penelitian Kualitatif tersedia di salah satu aplikasi belajar, yaitu Edmodo. Dengan demikian mahasiswa tidak perlu lagi merasa kebingungan jika tidak melakukan tatap muka dengan dosen, karena materi telah tersedia dengan baik. Namun 47,8\% responden menyatakan setuju dan tidak setuju jika perkuliahan daring dapat diakses dimanapun mereka berada. Artinya sebagian responden kesulitan dalam mengikuti perkuliahan daring tersebut. Hal ini diperkuat dengan 69,6\% yang menemui hambatan ketika mengikuti daring, dikarenakan kendala seperti kuota dan sinyal. Disisi lain pembelajaran daring dapat mempermudah dalam mendiskusikan pelajaran kepada dosen karena bisa didiskusikan secara langsung meskipun berada di tempat yang berbeda dan $43,5 \%$ setuju bahwa perkuliahan daring memudahkan mereka mengirim tugas tepat waktu serta $43,5 \%$ menyatakan tidak ada kerumitan belajar menggunakan metode daring karena didukung dengan kemudahan teknologi.

\section{Pembahasan}

\section{Persepsi Mahasiswa ditinjau dari Pengalaman Belajar}

Berdasarkan hasil analisis data diatas menunjukkan bahwa peserta didik (mahasiswa) menunjukkan persepsi negatif mengenai aspek pengalaman belajar selama perkuliahan daring dalam mata kuliah Metodologi Penelitian Kualitatif. Hal ini dapat dilihat dari sebagian besar mahasiswa yang mengalami kesulitan dalam mengikuti pembelajaran daring. Mereka berpendapat bahwa pembelajaran daring belum bisa menggantikan pembelajaran tatap muka di kelas selama pandemi Covid-19, meskipun $65,2 \%$ setuju bahwa mereka dapat menerima penjelasan dari dosen dengan jelas dan $60,9 \%$ mahasiswa sangat senang mengikuti perkuliahan secara daring.

Pembelajaran daring juga membuat mahasiswa mempunyai semangat belajar yang baik dan 52,2\% mahasiswa dapat memahami secara penuh ketika ada teman mereka yang 
melakukan presentasi. Hal ini dapat dilihat melalui wawancara yang telah dilakukan oleh dosen. Adapun kutipan wawancara adalah sebagai berikut:

Peneliti: Apa yang membuat kalian semangat belajar daring?

Responden: Saya bisa belajar kapan saja pak

Dan kutipan berikut: dan dimana saja. Jadi tidak ribet.

Peneliti: Apa kamu paham jika ada teman yang melakukan presentasi?

Responden: Insyaalloh paham pak, biasanya pak dosen memberikan instruksi waktu presentasi dan menegur jika kami salah.

Disisi lain, data yang didapat berdasarkan tabel 1 membuat dosen merasa khawatir jikalau mahasiswa mengalami stress dengaa banyaknya tugas yang diberikan oleh dosen. 56,5\% mahasiswa menyatakan kesulitan menerima materi Metodologi Penelitian Kualitatif. Padahal dosen telah memberikan RPS dan materi kepada mahasiswa. Terdapat sebuah persepsi yang berbeda antara dosen dan mahasiswa, sehingga capaian kompetensi belum sesuai dengan yang diharapkan. Mahasiswa tidak menikmati pembelajaran dan merasa pembelajaran daring itu sangat sulit, $56,5 \%$ mahasiswa setuju akan pernyataan tersebut. Selain itu, mahasiswa juga tidak menginginkan bila perkuliahan daring dilaksanakan secara berkelanjutan jika pandemi telah berakhir. Meskipun dosen telah memberikan materi pembelajaran, namun mahasiswa lebih merasa senang jika pembelajaran dilakukan secara tatap muka. Hal ini disebabkan oleh kurangnya pemahaman mahasiswa dalam menguasai materi dan tidak adanya buku ajar yang dimiliki oleh mahasiswa. Mereka lebih mengandalkan sumber bacaan dari internet dan kebiasaan mengcopy paste materi dari internet jika diberikan tugas oleh dosen. Maka dari itu pengalaman belajar mahasiswa dinilai sangat kurang.

\section{Persepsi Mahasiswa ditinjau dari Aspek Kapabilitas Dosen}

Dilihat dari aspek kapabilitas dosen, hasil analisis data menunjukkan bahwa mahasiswa memiliki persepsi positif. 65,2\% mahasiswa menyatakan jika dosen selalu memberikan perkuliahan daring selama pandemi Covid-19. Selain itu dosen juga menggunakan beberapa aplikasi pembelajaran seperti Edmodo, Zoom, Google Meet, dan Youtube dalam perkuliahan sehingga mahasiswa tidak mengalami kebosanan dalam belajar. Terlebih lagi, dosen juga memberikan penjelasan ketika menyampaikan materi sehingga membuat pembelajaran lebih menarik dan mudah dipahami. Materi disampaikan secara detail dan mendalam melalui Power Point, modul, gambar, dan video sehingga terjadilah diskusi interaktif di dalam kelas.

Lalu 78,3\% mahasiswa juga menyatakan setuju bahwa dosen telah memberikan arahan dan tujuan pembelajaran sebelum memulai pembelajaran. Selain itu dosen juga selalu memberikan bimbingan terhadap materi pembelajaran yang belum dipahami secara daring. Hal ini diperkuat dengan adanya faktor pendukung lain seperti stimulus, interaksi, dan umpan balik yang dilakukan secara kontinyu agar membuat mahasiswa merasakan kehadiran dan peran langsung dosen dalam pembelajaran meskipun dilakukan secara daring. Adapun kutipan wawancara sebagai berikut:

$$
\begin{gathered}
\text { Peneliti: Apa dosen juga membimbing } \\
\text { mahasiswa secara daring jika ada } \\
\text { materi yang gak dipahami? }
\end{gathered}
$$

Responden: Iya Pak, saat saya bingung, saya bisa langsung tanya ke dosen. Misal ya, saya bingung materi atau tugas, saya bisa tanya langsung lewat zoom tanpa harus ketemu, jadi sedikit membantu.

\section{Persepsi Mahasiswa ditinjau dari Aspek Sarana dan Prasarana}

Pada pelaksanaan pembelajaran berbasis e-learning, hal yang menjadi kebutuhan utama 
adalah kesiapan pembelajaran baik dari kesiapan SDM maupun sarana prasarana (Khusniyah \& Wana, 2020). Dilihat dari aspek sarana dan prasarana masih membutuhkan kajian lebih lanjut dikarenakan adanya keterbatasan dan hambatan yang dialami oleh mahasiswa selama ini sehingga persepsi yang dihasilkan adalah negatif. Padahal 60,9\% mahasiswa setuju bahwa materi perkuliahan Metodologi Penelitian Kualitatif tersedia dengan baik di salah satu aplikasi belajar, yaitu Edmodo.

Namun di sisi lain, sebanyak 69,6\% menyatakan bahwa banyak hambatan yang ditemui ketika pelaksanaan perkuliahan seperti kuota, sinyal, dan perangkat elektronik. Mereka juga sangat serius mengalami hambatan jaringan internet karena sinyal yang sangat lemah dan kuota yang sangat mahal sehingga permasalahan tersebut tidak dapat dihindarkan. Meskipun mereka sudah mendapatkan bantuan kuota dari pemerintah, tetapi pada faktanya hanya beberapa Gigabyte saja yang bisa digunakan untuk Zoom dan Google Meet. Selain itu faktor lokasi juga berpengaruh terhadap kuat atau tidaknya sinyal yang digunakan oleh mahasiswa.

Perangkat elektronik yang dipakai pun menjadi salah satu penghambat yang sangat mengkhawatirkan karena tidak semua mahasiswa mempunyai perangkat elektronik yang sesuai standar untuk belajar secara daring. Mereka lebih banyak yang menggunakan perangkat handphone ketika mengikuti perkuliahan, dan hanya sedikit yang menggunakan laptop sehingga mengalami kesukaran ketika presentasi dan sulitnya memahami penjelasan materi melalui power point.

Sebanyak 47,8\% tidak setuju jika pembelajaran daring dapat mempermudah mendiskusikan dan mengakses tugas. 43,5\% juga menyatakan tidak setuju jika tidak ada kerumitan dalam penerapan daring. Hal ini menyatakan bahwa responden menunjukkan ketidakpuasan dengan pembelajaran daring yang selama ini mereka ikuti dilihat dari aspek sarana dan prasarana. Sarana dan prasarana, khususnya kuota internet dan sinyal menjadi komponen yang mendapat tempat pertama sebagai pendukung terselenggaranya pembelajaran daring.

Namun disisi lain, 43,5\% setuju bahwa pembelajaran daring bisa memudahkan mahasiswa dalam mengirim tugas tepat waktu, sehingga mahasiswa tidak perlu pergi ke kampus untuk mengumpulkan tugas. Hal ini juga mempermudah mahasiswa dalam hal efektivitas dan efisiensi dalam belajar.

\section{PENUTUP}

\section{Simpulan}

Perkuliahan daring yang dilaksanakan di bidang pendidikan karena adanya pandemi Covid-19 sudah berjalan selama beberapa waktu belakangan. Situasi yang sebelumnya belum pernah dirasakan, akhirnya harus terjadi tanpa ada persiapan terlebih dahulu. Hal ini mengakibatkan revolusi dalam dunia pendidikan yang harus bisa diadaptasi oleh pendidik dan peserta didik agar pembelajaran tetap terlaksana dengan baik. Mereka harus memiliki pemahaman yang baik dalam kegiatan belajar mengajar, salah satunya adalah pemahaman persepsi pembelajaran. Adapun hasil dari penelitian yang telah dilakukan disimpulkan bahwa persepsi mahasiswa ditinjau dari aspek kapabilitas dosen menunjukkan persepsi positif selama perkuliahan daring. Hal ini dikarenakan dosen menggunakan beberapa aplikasi pembelajaran seperti Edmodo, Zoom, Google Meet, dan Youtube dalam perkuliahan sehingga mahasiswa tidak mengalami kebosanan dalam belajar. Materi pembelajaran juga disampaikan secara detail dan mendalam melalui Power Point, modul, gambar, dan video sehingga terjadilah diskusi interaktif di dalam kelas. 
Namun melalui data analisis yang sama, mahasiswa memiliki persepsi negatif ditinjau dari aspek pengalaman belajar dan aspek sarana prasarana. Dari aspek pengalaman belajar, kurangnya pemahaman materi dan tidak adanya buku ajar yang dimiliki menjadi faktor utama. Selain itu, mahasiswa mengalami stress dengan adanya banyaknya tugas yang diberikan oleh dosen. Dari aspek sarana prasarana, mahasiswa mengalami kesulitan dalam mengikuti pembelajaran daring dikarenakan kurangnya kuota, lemahnya sinyal, dan terbatasnya perangkat elektronik yang sesuai dengan standar belajar daring.

\section{Saran}

Berdasarkan beberapa temuan tersebut, diharapkan pemimpin perguruan tinggi dapat melaksanakan perkuliahan daring dengan platform yang lebih mudah dan tidak membutuhkan kuota yang besar. Dosen juga harus meningkatkan kompetensi dengan sajian materi yang lebih bervariasi dan menyenangkan sehingga mahasiswa mudah memahami materi pembelajaran. Materi diharapkan lebih nyaman diakses oleh mahasiswa melalui sebuah aplikasi yang nyaman dan berintegrasi (satu pintu).

\section{DAFTAR PUSTAKA}

Allo, M. D. G. (2020). Is the online learning good in the midst of Covid-19 Pandemic? The case of EFL learners. 10(1), 10.

Keengwe, J., \& Georgina, D. (2012). The digital course training workshop for online learning and teaching. Education and Information Technologies, 17(4), 365379. https://doi.org/10.1007/s10639-0119164-x

Khusniyah, T. W., \& Wana, P. R. (2020). PERSEPSI MAHASISWA PGSD PADA INOVASI PEMBELAJARAN BERBASIS E-LEARNING. Wahana Sekolah Dasar, 28(1), 1-10.

Horton, William. (2010). E-Learning By Design. United States Of America: Preiffer an Imprint Of Willey.
Sarwono, Sarlito W. (2014). Psikologi Lintas Budaya. Jakarta: Rajawali Pers.

Siagian, Sondang P. (1995). Teori Motivasi dan Aplikasinya. Jakarta: Rineka Cipta.

Siregar, Evelin dan Hartini Nara. (2011). Teori Belajar dan Pembelajaran. Bogor: Ghalia Indonesia 